JOSAR, Vol. 1 No. 2 September, 2018; p-ISSN: 2502-8251; e-ISSN: 2503-1155

Copyrights@ Balitar Islamic University, Blitar-Indonesia https://ejournal.unisbablitar.ac.id/index.php/josar

\title{
FEASIBILITY OF THE THREE DIMENSIONS OF THE CROSSED ANGIOSPERMAE PLANT FOR XI GRADE STUDENTS
}

\author{
Nunung Nur Latifah'1), Maratus Sholihah²), Dian Puspita Anggraini3) \\ 1,2 Islamic University of Balitar; J. Majapahit No.04, Telp. (0342) 813145 \\ ${ }^{3}$ Biology Education, FKIP Islamic University of Balitar;, Blitar \\ e-mail: ${ }^{* 1}$ nununglatifah806@yahoo.com
}

\begin{abstract}
This study aims to determine the feasibility of the three dimensional cross section of the stem of the Angiosperm plant. This type research is Research and Development $(R \& D)$ with a $4 D$ development model that is limited to the development stage. This research through assessment by material experts, media and language with an average score of $82.6 \%$ with a very valid category. Assessment of teacher responses score of $86.1 \%$ with a very valid category. Assessment of student responses to limited scale trials was 92\% with very good categories. Three dimensional cross section of Angiosperm plant stem is very valid for use in classroom learning activities.
\end{abstract}

Keywords: Research development, Three dimensions, Angiosperm stem

\section{INTRODUCTION}

Teaching and learning activities are processes that can influence students in achieving educational goals. The purpose of education can be achieved if there are changes in behavior, morals and social attitudes to students obtained through a learning environment that is regulated by the teacher through the teaching process. The teaching process requires a learning media to deliver lesson material. Media is an intermediary or delivery tool. Learning media can be used as a means of connecting to achieve the message that must be achieved by students in learning activities.

Learning media can provide a real picture of material concepts that cannot be directly observed. One such material that is considered difficult is plant tissue. Based on observations made in three high school schools as much as $60.2 \%$ of students have difficulty understanding the material. In accordance with interviews conducted with biology teachers, plant tissue material is usually carried out by practicum. Practicum can provide a 
JOSAR, Vol. 1 No. 2 September, 2018; p-ISSN: 2502-8251; e-ISSN: 2503-1155

Copyrights@ Balitar Islamic University, Blitar-Indonesia https://ejournal.unisbablitar.ac.id/index.php/josar

real picture and can improve the skills of students. But, in doing practicum, it must be equipped with adequate facilities.

Through observations made, not all high school schools have adequate facilities for practicum. For this reason, an artificial object is needed which can be used as a substitute for practical activities. Thus, three-dimensional media can be used as props on material whose object is not possible to be presented into the class.

Three-dimensional media is a medium that has dimensions of length, width, and thickness so that it can be observed from all directions. A threedimensional media group can be in the form of an original object or an imitation formed the same as the original object. Three-dimensional media can help students understand abstract things to be concrete, and complex things become simpler. So that students will more easily understand the material.

The development of three-dimensional media is supported by previous research conducted by Jonkenedi (2017), Khoirunnisa (2014) and Krisnawati (2013). The results of the study indicate that a decent three-dimensional media can be used as a medium of learning in the classroom. The purpose of the study was to determine the feasibility of three-dimensional cross-section of the stem of the Angiosperm plant for high school students of class XI.

\section{RESEARCH METHODS}

The approach used in this study is quantitative and qualitative approaches. Quantitative data in the form of assessment scores from expert teams. Qualitative data in the form of advice and input from the expert team. The research design used was Research and Development (R\&D) with the Thiagarajan 4D development model, et al. Consisting of define, design, development without dissemination. 
JOSAR, Vol. 1 No. 2 September, 2018; p-ISSN: 2502-8251; e-ISSN: 2503-1155

Copyrights@ Balitar Islamic University, Blitar-Indonesia https://ejournal.unisbablitar.ac.id/index.php/josar

The research procedure begins with the stages of defining, designing, and developing. The defining stage is done to find out the needs in the learning process and products that are developed through front end analysis, student analysis, task analysis, concept analysis and formulating objectives. The design phase that is carried out is compiling the test, selecting the media, choosing the format and preparing the initial design of the product. The development stage is a process to produce a product that is feasible to use through validation by a team of experts.

The product specifications developed are three-dimensional media in the form of a replica cross-section model of the Angiosperm plant (monocot and dicot). This three-dimensional media-making material is Styrofoam which is in the shape of a quarter circle and is affixed to the board. Styrofoam used has a thickness of $1.5 \mathrm{~cm}$. The board used is \pm 50 $\mathrm{cm} \times 33 \mathrm{~cm}$ in size. Three-dimensional media formed by a quarter circle \pm $15 \mathrm{~cm}$ in diameter with a thickness of $\pm 5 \mathrm{~cm}$. Media is made like a puzzle arranged. The media is equipped with a user manual for students and for teachers measuring A5.

Products that are deemed feasible by experts can be used for product testing. Product testing is done on a limited scale to determine student responses. The instruments in this study used expert validation questionnaire sheets, teacher response assessment sheets and student response sheets. Data analysis techniques in the form of qualitative and quantitative data. Qualitative data in the form of advice and input from experts. Quantitative data in the form of scores from expert teams, teacher ratings and student responses. The calculation of the assessment by the expert team and the assessment by the teacher uses the following 
JOSAR, Vol. 1 No. 2 September, 2018; p-ISSN: 2502-8251; e-ISSN: 2503-1155

Copyrights@ Balitar Islamic University, Blitar-Indonesia https:/lejournal.unisbablitar.ac.id/index.php/josar

formula:

$$
\mathrm{P}=\frac{\sum x}{\sum x i} \times 100 \%
$$

Information :

$$
\begin{aligned}
& \mathrm{P}=\text { percentage sought } \\
& \Sigma \mathrm{x}=\text { Amount of respondent's answer } \\
& \Sigma \mathrm{xi}=\text { Amount of ideal value }
\end{aligned}
$$

The eligibility criteria from the validation sheet are filled in, then matched with reference to Table 1.

\begin{tabular}{lc} 
& Table 1. Criteria for level of validity \\
\hline Percentage (\%) & Validation Criteria \\
\hline $76-100$ & Very Worthy \\
$56-75$ & Eligible \\
$40-55$ & Less Worthy \\
$0-39$ & Not Eligible \\
\hline
\end{tabular}

(Source: Arikunto, 2012)

Calculation of student questionnaire responses using the following formula:

$$
P=\frac{n}{N} \times 100 \%
$$

Information:

$$
\begin{aligned}
& \mathrm{P}=\text { feasibility score } \\
& \mathrm{N}=\text { the maximum number of expected scores. } \\
& \mathrm{n}=\text { the maximum number of scores obtained. }
\end{aligned}
$$

The results of the percentage of student responses are adjusted to the criteria in Table 2.

Table 2. Criteria for percentage assessment scores

\begin{tabular}{lc}
\hline$\%$ Score interval & Criteria \\
\hline $81,25 \%<$ skor $\leq 100 \%$ & Very good \\
$62,50 \%<$ skor $\leq 81,25 \%$ & Good \\
$43,75 \%<$ skor $\leq 62,50 \%$ & Less good \\
$25 \%<$ skor $\leq 43,75 \%$ & Not good \\
\hline (Source: Arikunto, 2012) &
\end{tabular}

\section{RESULTS AND DISCUSSION}


JOSAR, Vol. 1 No. 2 September, 2018; p-ISSN: 2502-8251; e-ISSN: 2503-1155

Copyrights@ Balitar Islamic University, Blitar-Indonesia https:/lejournal.unisbablitar.ac.id/index.php/josar

The development of the three-dimensional cross-sectional media of the stem of the Angiosperm plant was validated by material experts, media experts and linguists. The results of expert validation are shown in Tables 3, 4 and 5. The results of teacher evaluations and student responses are shown in Tables 6 and 7.

Table 3. Results of material expert validation

\begin{tabular}{|c|c|c|c|c|c|}
\hline \multirow[t]{2}{*}{ No } & \multirow[t]{2}{*}{ Description } & \multicolumn{3}{|c|}{ Scores } & \multirow{2}{*}{$\begin{array}{c}\text { Catego } \\
\mathrm{y}\end{array}$} \\
\hline & & $\begin{array}{c}\text { Validator } \\
1\end{array}$ & Validator 2 & Validator 3 & \\
\hline 1. & Relevance & 13 & 13 & 15 & \multirow{6}{*}{$\begin{array}{l}\text { Very } \\
\text { valid }\end{array}$} \\
\hline 2. & Serves & 8 & 10 & 10 & \\
\hline 3. & Benefits & 13 & 14 & 13 & \\
\hline & Total score & 34 & 37 & 38 & \\
\hline & $\begin{array}{l}\text { rcentage of total } \\
\text { score in }(\%)\end{array}$ & $85 \%$ & $92,5 \%$ & $95 \%$ & \\
\hline & $\begin{array}{l}\text { average score of } \\
\text { naterial experts }\end{array}$ & \multicolumn{3}{|c|}{$90,8 \%$} & \\
\hline
\end{tabular}

Based on the table above the percentage of assessment by material experts found a score of $90.8 \%$ with information very feasible to use for classroom learning activities.

Table 4. Results of media expert validation

\begin{tabular}{|c|c|c|c|c|c|}
\hline \multirow{2}{*}{$\begin{array}{c}\text { No } \\
\text {. }\end{array}$} & \multirow[t]{2}{*}{ Description } & \multicolumn{3}{|c|}{ Scores } & \multirow{2}{*}{$\begin{array}{c}\text { Categor } \\
y\end{array}$} \\
\hline & & $\begin{array}{c}\text { Validator } \\
1\end{array}$ & Validator 2 & Validator 3 & \\
\hline 1. & Display & 15 & 15 & 20 & \multirow{6}{*}{ valid } \\
\hline 2. & Materials & 9 & 11 & 14 & \\
\hline 3. & Benefits & 6 & 5 & 7 & \\
\hline & Total score & 30 & 31 & 41 & \\
\hline & $\begin{array}{l}\text { rcentage of total } \\
\text { score in }(\%)\end{array}$ & $60 \%$ & $62 \%$ & $82 \%$ & \\
\hline & $\begin{array}{l}\text { lia expert average } \\
\text { score }\end{array}$ & \multicolumn{3}{|c|}{$68 \%$} & \\
\hline
\end{tabular}

The results of the assessment by media experts get a score of $68 \%$. According to Arikunto (2012), a media can be said to be feasible if it scores $56 \%-75 \%$. So that the assessment of media experts can be said to be worthy of being used as a medium of learning in the classroom. 
JOSAR, Vol. 1 No. 2 September, 2018; p-ISSN: 2502-8251; e-ISSN: 2503-1155

Copyrights@ Balitar Islamic University, Blitar-Indonesia https:/lejournal.unisbablitar.ac.id/index.php/josar

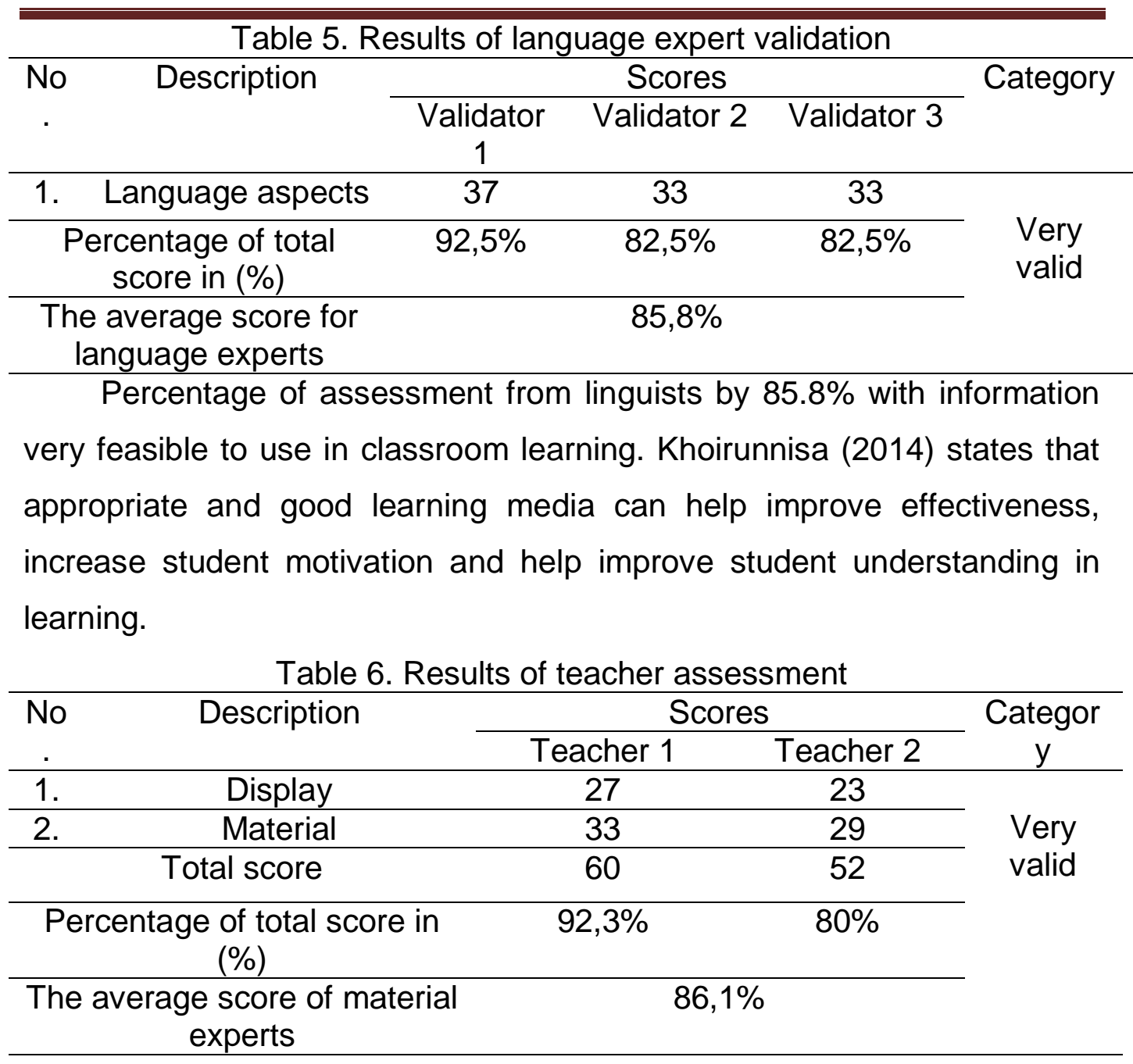

Based on the table above, the percentage of assessment by the teacher obtained is $86.1 \%$ with information very feasible to use for classroom learning activities.

Table 7. Results of student responses

\begin{tabular}{|c|c|c|c|c|c|c|c|c|c|}
\hline \multirow[b]{2}{*}{ No. } & \multirow[b]{2}{*}{ Name } & \multicolumn{7}{|c|}{ Statement } & \multirow[b]{2}{*}{ Score } \\
\hline & & 1 & 2 & 3 & 4 & 5 & 6 & 7 & \\
\hline 1 & Student-1 & 5 & 4 & 5 & 5 & 4 & 4 & 5 & 32 \\
\hline 2 & Student-2 & 5 & 4 & 4 & 5 & 4 & 4 & 5 & 31 \\
\hline 3 & Student -3 & 5 & 4 & 5 & 5 & 4 & 4 & 5 & 32 \\
\hline 4 & Student -4 & 5 & 5 & 4 & 5 & 5 & 5 & 5 & 34 \\
\hline 5 & Student -5 & 5 & 4 & 5 & 5 & 4 & 4 & 5 & 32 \\
\hline \multicolumn{9}{|c|}{ Total score } & 161 \\
\hline \multicolumn{9}{|c|}{ Maximum score } & 175 \\
\hline \multicolumn{9}{|c|}{ Percentage } & $92 \%$ \\
\hline
\end{tabular}


JOSAR, Vol. 1 No. 2 September, 2018; p-ISSN: 2502-8251; e-ISSN: 2503-1155

Copyrights@ Balitar Islamic University, Blitar-Indonesia https://ejournal.unisbablitar.ac.id/index.php/josar

The results of the response to the limited-scale trials obtained a score of $92 \%$ with very good information used for classroom learning activities. Research conducted by Khoirunnisa (2014), by implementing three-dimensional media development networks of constituent dicotyledonous stems as biology teaching materials. The use of threedimensional media is arranged according to needs and get a good response by students. So that three-dimensional media is feasible to be implemented in the teaching and learning process. According to Krisnawati (2013) the results of developing three-dimensional media that are feasible in learning activities will affect the improvement of student learning outcomes. Jonkenedi (2017) also states that proper use of threedimensional media in learning can increase student activity and activities in learning increasingly varied so that the learning process is more enjoyable. So that overall the three-dimensional cross-section of the Angiosperm plant stem is suitable for use in classroom learning activities.

\section{CONCLUSIONS AND SUGGESTIONS}

\section{A. CONCLUSION}

Based on the results of the study showed that the three-dimensional cross section of the Angiosperm plant stem is suitable to be used as a medium of learning in the classroom. The feasibility of the media is obtained from the score of the experts' assessment with an average score of $82.6 \%$. Based on the teacher's response a score of $86.1 \%$ was obtained. While student responses obtained through trials on a scale are limited to getting a score of $92 \%$.

\section{B. SUGGESTION}

It is recommended that the stages developed be carried out until the deployment stage and the materials used are better which are more durable and not susceptible to damage. 
JOSAR, Vol. 1 No. 2 September, 2018; p-ISSN: 2502-8251; e-ISSN: 2503-1155

Copyrights@ Balitar Islamic University, Blitar-Indonesia https://ejournal.unisbablitar.ac.id/index.php/josar

\section{REFERENCES}

Arikunto. 2012. The Basic Foundation Of Education Evaluation Eedition 2. Jakarta: PT. Bumi Aksara.

Daryanto. 2010. Instructional Media. Yogyakarta: Gava Media.

Jonkenedi. 2017. The use of three-dimensional media to increase the activity of students in IPA learning. Journal of Primary School Teacher Education (6) (6): 590-598

Khoirunnisa. 2014. Development of three-dimensional media in the network of compilers of dicotyledonous stems as grade VIII SMP / MTS biology teaching materials. Essay. Faculty of Science and Technology. Sunan Kalijaga State Islamic University, Yogyakarta.

Krisnawati A. 2013. The use of three-dimensional media to improve learning outcomes in elementary schools. Journal of PGSD 2 (1): 17.

Sadiman S, Arief, Rahardjo, Haryono A, Rahardjito. 2007. Media Education. Jakarta: PT RajaGrafindo Persada.

Sudjana N, Rivai A. 2013. Teaching Media. Bandung: Sinar Baru Algensindo.

Sugiyono. 2016. Research Methods. Bandung: Alfabeta. 